Круш П.В.

канд. економ. наук, професор

Мастюк Д.О.

Національний технічний університет України «КПІ»

\title{
ДІАГНОСТИКА ЕФЕКТИВНОСТІ СТРУКТУРИ ВЛАСНОГО КАПІТАЛУ ЕНЕРГОГЕНЕРУЮЧИХ КОМПАНІЙ
}

\author{
ДИАГНОСТИКА ЭФФЕКТИВНОСТИ СТРУКТУРЫ СОБСТВЕННОГО \\ КАПИТАЛА ЭНЕРГОГЕНЕРИРУЮЩИХ КОМПАНИЙ
}

\section{DIAGNOSIS OF EQUITY STRUCTURE EFICIENCY AT THE POWER-PRODUCING COMPANIES}

Стаття присвячена процесу діагностики ефективності структури власного капіталу енергогенеруючих компаній. В статті удосконалено науково-методичний підхід до діагностики ефективності структури власного капіталу акціонерних товариств енергетики. Визначено основні стадї діагностики та коефіцієнти ефективності структури власного капіталу акиіонерних товариств. На його основі досліджено структуру власного капіталу п'яти енергогенеруючих акціонерних товариств, визначено ступінь ї̈ ефективності, обтрунтовано основні тенденції розвитку. Крім того, виділено ключові проблеми, що пов'язані з неоптимальним співвідношенням елементів структури капіталу енергогенеруючих компаній. Надано практичні рекомендащії щзод удосконалення структури власного капіталу та підвищення ступеню ї ефективності. Такими рекомендаціями є підтримка забезпечення активів власним капіталом на рівні 9-15\%, фінансування частки активів за рахунок нерозподіленого прибутку, погашення значної частини короткострокової заборгованості для зменшення рівня фінансового тиску на підприємство, регулювання процесу випуску акцій та виведення частини з них для реалізації на фондовий ринок. Пропоновані рекомендації дадуть змогу оптимізувати структуру власного капіталу акціонерних товариств та підвищити рівень ї̈ ефективності.

Ключові слова: власний капітал, структура капіталу, ефективність, енергогенеруючі компанії.

Статья посвящена проиессу диагностики эффективности структуры собственного капитала энергогенерирующих компаний. $B$ статье усовершенствован научнометодический подход к диагностике эффективности структуры собственного капитала акционерных обществ энергетики. Определены основные стадии диагностики эффективности структуры собственного капитала акционерных обществ. Было выделено основные коэффициенты эффективности структуры собственного капитала акционерных обществ. На основе усовершенствованного подхода, исследовано структуру собственного капитала пяти энергогенерирующих акционерных обществ, а также определенно степень её эффективности. После чего, обосновано основные тендениии развития структуры капитала и ее эффективности для энергогенерирующих акиионерных обществ. Кроме того, выделено ключевые проблемы, которые связаны с неоптимальным соотношением элементов структуры капитала энергогенерирующих компаний. 
Предоставлено практические рекомендачии по усовершенствованию структуры собственного капитала и повышению степени эффективности. Такими рекомендациями являются поддержка обеспечения активов собственным капиталом на уровне 9-15\%, финансирование части активов за счет нераспределенной прибыли, погашение существенной части краткосрочной задолженности для уменьшения уровня финансового давления, регулирование прочесса выпуска акиий и вывод их части для реализации на фондовый рынок. Данные рекомендаџии помогут сбалансировать структуру собственного капитала акционерных обществ и повысить уровень её эффективности.

Ключевые слова: собственный капитал, структура капитала, эффективность, энергогенерирующие компании.

The article is dedicated diagnostic process of the equity structure efficiency of the power generating companies. In the article, the scientific and methodical approach to diagnostic of efficiency of equity structure at the power generating corporations is improved. The crucial stages of efficiency diagnostic of equity structure at the power generating companies. The article highlights the main factors of the equity structure efficiency of joint stock companies. Based on the advanced approach, the structure of equity of five power generation corporations and the degree of its efficiency were investigated. On this basis, the main trends of equity structure and its efficiency for power generation corporations were grounded. In addition, the research highlights the key problems associated with optimal equity structure of elements of power generating companies. Practical recommendations for improving the equity structure and its performance were introduced. These provided recommendations are to support equity share at the 9-15\% level form the assets, to support financing through retained earnings, to repay a large part of shortterm debt in order to reduce the level of financial pressure. Besides, to regulate of the issue of shares and set their part at the stock market. The implemented recommendations will make it possible to balance the equity structure of joint stock companies and increase its effectiveness.

Keywords: equity, equity structure, efficiency, energy-producing companies.

Вступ. В період значних економічних змін енергогенеруючі компанії стикаються з рядом серйозних проблем, які потребують вирішення. Однією 3 таких є оптимізація структури власного капіталу, підвищення рівня їі ефективності та забезпечення стабільності, оскільки власний капітал виступає фундаментом розвитку підприємства, матеріально-технічної бази, його фінансової незалежності та інвестиційної привабливості.

Питанню оцінки структури капіталу підприємства, в тому числі i власного капіталу, приділяється значна кількість як іноземних, так i вітчизняних публікацій. Серед вітчизняних вчених можна виділити праці Мойсеєнка І.П. [1], Косової Т.Д. [2], Мартиненка В.П., Климаш Н.І. [3] тощо. Серед іноземних на увагу заслуговують праці Балверса Л.Дж., Хуанга Д. [4], Радулеску А., Пеле Д.Т. [5] тощо. Проте, комплексна діагностика ефективності структури капіталу підприємств визначає результат 3 урахуванням усіх джерел фінансування діяльності підприємства, не виділяючи при цьому окремим елементом власний капітал і не акцентуючи увагу на його ефективному використанні. Відтак, важливим питанням є саме діагностування ефективність структури власного капіталу енергогенеруючих 
компаній, управління його структурою для забезпечення стабільного розвитку, підтримки економічної безпеки.

Постановка завдання. Метою дослідження $є$ здійснення діагностики ефективності структури власного капіталу енергогенеруючих компаній. На основі поставленої мети сформульовано низка завдань:

1) удосконалити науково-методичний підхід до діагностування ефективності структури власного капіталу енергогенеруючих акціонерних товариств;

2) дослідити ефективність структури власного капіталу енергогенеруючих компаній, виділити основні проблеми та тенденції ії зміни;

3) надати рекомендації щодо удосконалення структури власного капіталу.

Методологія. Під час проведення дослідження було використано методи аналізу та синтезу - при вивчені окремих складових структури власного капіталу підприємства та групуванні результатів дослідження; метод коефіцієнтів - для розрахунку базових показників аналізу власного капіталу та визначення часток елементів його структури; графічний метод - в процесі побудови узагальнених графіків та схеми методики аналізу власного капіталу; системний підхід, метод узагальнень, логічний - для надання відповідних висновків та практичних рекомендацій на основі здійснених розрахунків.

Результати дослідження. Аналізуючи методичні підходи до діагностики структури капіталу, представлені у ряді наукових праць [1-3] було зроблено висновок про доцільність удосконалення науково-методичного підходу до діагностики ефективності саме структури власного капіталу (ВК) енергогенеруючих акціонерних товариств. Схематично підхід до діагностики ефективності структури власного капіталу можна зобразити наступним чином (рис. 1): 
Збір даних по структурі власного капіталу акціонерного товариства

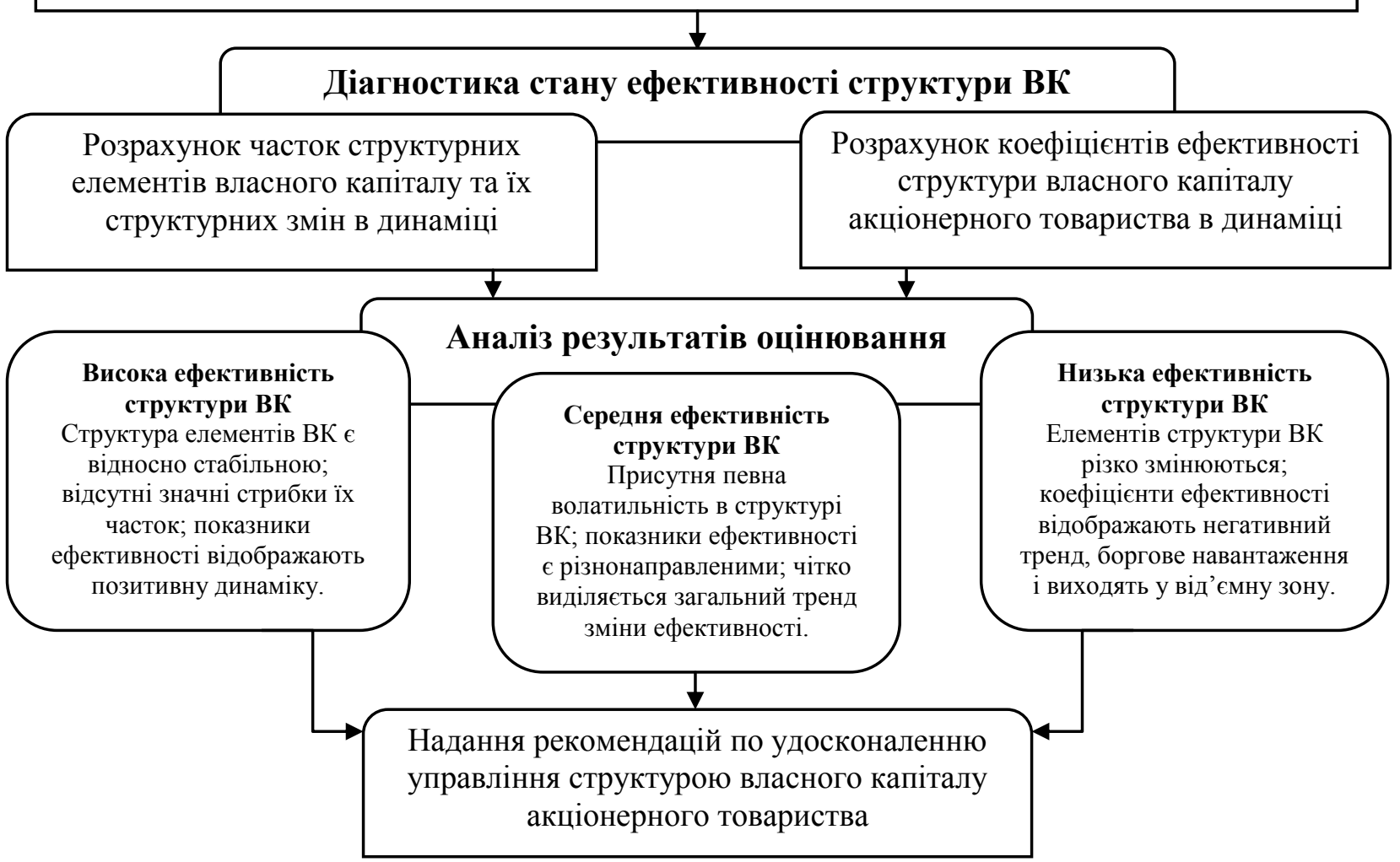

Рис. 1. Науково-методичний підхід до діагностики ефективності структури власного капіталу акціонерного товариства енергетики *удосконалено автором на основі [1-6]

Наведені показники визначають структурні зміни власного капіталу підприємства та ефективність його використання. Проте необхідно опиратись також і на інші показники мікро та макрорівня, звертати увагу на політику фінансування та модель ринку, на якому функціонує підприємство [4; 5].

Використовуючи наведений підхід проведемо діагностику власного капіталу обраних акціонерних товариств енергетики. Базою для дослідження є п’ять енергогенеруючих компаній: ПАТ «Центренерго», ПАТ «Київенерго», ПАТ «Західенерго», ПАТ «Донбасенерго» та ПАТ «Дніпроенерго» [8].

Розглянемо детально структуру власного капіталу обраних підприємств (таблиця). Загальний тренд зміни частки статутного капіталу у загальній структурі власного капіталу ПАТ «Центренерго»є спадним. 32010 року по 2013 спостерігається падіння частки останнього до рівня 19,18\%. Основною причиною даної зміни можна назвати зростання частки нерозподіленого прибутку підприємства та розміру резервного капіталу. Максимум нерозподіленого прибутку в балансовій структурі власного капіталу припадає на 2012 рік і становить 69,40\%, а станом на 2013 рік - 67,96\%. 32014 року відбувається падіння частки нерозподіленого прибутку на 15,03\%. 
Таблиця

Динаміка структурних змін власного капіталу ПАТ «Центренерго»

\begin{tabular}{|c|c|c|c|c|c|c|}
\hline \multirow{2}{*}{ Елемент власного капіталу } & \multicolumn{6}{|c|}{ Частка елементу власного капіталу } \\
\hline & 2010 & 2011 & 2012 & 2013 & 2014 & 2015 \\
\hline 1 & 2 & 3 & 4 & 5 & 6 & 7 \\
\hline \multicolumn{7}{|c|}{ ПАТ «Центренерго» } \\
\hline Статутний капітал & $26.3 \%$ & $25.77 \%$ & $23.02 \%$ & $19.18 \%$ & $19.78 \%$ & $22.41 \%$ \\
\hline Інший додатковий капітал & $121.02 \%$ & $6.54 \%$ & $6.94 \%$ & $11.85 \%$ & $25.25 \%$ & $28.61 \%$ \\
\hline Резервний капітал/ВК & $0.62 \%$ & $0.63 \%$ & $0.65 \%$ & $1.01 \%$ & $2.04 \%$ & $2.31 \%$ \\
\hline $\begin{array}{l}\text { Нерозподілений прибуток } \\
\text { (непокритий збиток) }\end{array}$ & $-47.94 \%$ & $67.06 \%$ & $69.40 \%$ & $67.96 \%$ & $52.93 \%$ & $46.67 \%$ \\
\hline $\begin{array}{l}\text { Резервний капітал/Статутний } \\
\text { капітал }\end{array}$ & $2.34 \%$ & $2.44 \%$ & $2.81 \%$ & $5.24 \%$ & $10.31 \%$ & $10.31 \%$ \\
\hline \multicolumn{7}{|c|}{ ПАТ «Київенерго» } \\
\hline Статутний капітал & $1.74 \%$ & $0.57 \%$ & $0.68 \%$ & $0.61 \%$ & $0.60 \%$ & $0.68 \%$ \\
\hline Додатково вкладений капітал & $0 \%$ & $0 \%$ & $48.15 \%$ & $42.41 \%$ & $41.55 \%$ & $42.04 \%$ \\
\hline Інший додатковий капітал & $147.85 \%$ & $64.86 \%$ & $31.96 \%$ & $32.56 \%$ & $38.12 \%$ & $44.33 \%$ \\
\hline Резервний капітал/ВК & $4.16 \%$ & $0 \%$ & $0 \%$ & $0 \%$ & $0 \%$ & $0 \%$ \\
\hline $\begin{array}{l}\text { Нерозподілений прибуток } \\
\text { (непокритий збиток) }\end{array}$ & $-53.75 \%$ & $34.57 \%$ & $19.21 \%$ & $24.43 \%$ & $19.73 \%$ & $12.95 \%$ \\
\hline $\begin{array}{l}\text { Резервний капітал/Статутний } \\
\text { капітал }\end{array}$ & $238 \%$ & $0 \%$ & $0 \%$ & $0 \%$ & $0 \%$ & $0 \%$ \\
\hline \multicolumn{7}{|c|}{ ПАТ «Західенерго» } \\
\hline Статутний капітал & $25.22 \%$ & $90.58 \%$ & $94.45 \%$ & $7.52 \%$ & $5.28 \%$ & $14.90 \%$ \\
\hline Інший додатковий капітал & $288.19 \%$ & $0 \%$ & $0 \%$ & $22.51 \%$ & $39.85 \%$ & $85.04 \%$ \\
\hline Резервний капітал/ВК & $1.49 \%$ & $0 \%$ & $0 \%$ & $0 \%$ & $0 \%$ & $0 \%$ \\
\hline $\begin{array}{l}\text { Нерозподілений прибуток } \\
\text { (непокритий збиток) }\end{array}$ & $-214.9 \%$ & $9.42 \%$ & $5.55 \%$ & $69.96 \%$ & $54.87 \%$ & $0.06 \%$ \\
\hline $\begin{array}{l}\text { Резервний капітал/Статутний } \\
\text { капітал }\end{array}$ & $5.90 \%$ & $0 \%$ & $0 \%$ & $0 \%$ & $0 \%$ & $0 \%$ \\
\hline \multicolumn{7}{|c|}{ ПАТ «Донбасенерго» } \\
\hline Статутний капітал & $34.41 \%$ & $34.43 \%$ & $35.91 \%$ & $19.49 \%$ & $18.62 \%$ & $18.22 \%$ \\
\hline Додатково вкладений капітал & $0 \%$ & $0 \%$ & $0 \%$ & $1.66 \%$ & $28.84 \%$ & $33.28 \%$ \\
\hline Інший додатковий капітал & $123.92 \%$ & $129.03 \%$ & $0 \%$ & $0 \%$ & $0 \%$ & $0 \%$ \\
\hline Резервний капітал/ВК & $0.3 \%$ & $0.3 \%$ & $0.32 \%$ & $0.3 \%$ & $2.38 \%$ & $2.72 \%$ \\
\hline $\begin{array}{l}\text { Нерозподілений прибуток } \\
\text { (непокритий збиток) }\end{array}$ & $-58.64 \%$ & $-63.76 \%$ & $63.77 \%$ & $78.63 \%$ & $50.16 \%$ & $45.78 \%$ \\
\hline Вилучений капітал & $0 \%$ & $0 \%$ & $0 \%$ & $-0.08 \%$ & $0 \%$ & $0 \%$ \\
\hline $\begin{array}{l}\text { Резервний капітал/Статутний } \\
\text { капітал }\end{array}$ & $0.88 \%$ & $0.88 \%$ & $0.88 \%$ & $1.54 \%$ & $12.78 \%$ & $14.91 \%$ \\
\hline \multicolumn{7}{|c|}{ ПАТ «Дніпроенерго» } \\
\hline Статутний капітал & $6.91 \%$ & $6.13 \%$ & $4.09 \%$ & $2.26 \%$ & $1.98 \%$ & $2.11 \%$ \\
\hline Додатково вкладений капітал & $46.36 \%$ & $27.26 \%$ & $18.18 \%$ & $15.17 \%$ & $13.27 \%$ & $14.18 \%$ \\
\hline Інший додатковий капітал & $131.17 \%$ & $68.02 \%$ & $57.83 \%$ & $42.91 \%$ & $35.7 \%$ & $52.4 \%$ \\
\hline Резервний капітал/ВК & $0.41 \%$ & $0.5 \%$ & $0.59 \%$ & $0.49 \%$ & $0.43 \%$ & $0.46 \%$ \\
\hline $\begin{array}{l}\text { Нерозподілений прибуток } \\
\text { (непокритий збиток) }\end{array}$ & $-84.85 \%$ & $-1.91 \%$ & $19.31 \%$ & $39.16 \%$ & $48.62 \%$ & $30.84 \%$ \\
\hline $\begin{array}{l}\text { Резервний капітал/Статутний } \\
\text { капітал }\end{array}$ & $5.92 \%$ & $8.12 \%$ & $14.47 \%$ & $21.84 \%$ & $21.84 \%$ & $21.84 \%$ \\
\hline
\end{tabular}


Резервний капітал ПАТ «Центренерго» за даний проміжок часу набуває максимуму в першій половині 2015 року і становить $2,31 \%$ від загальної структури та 10,31\% від статутного капіталу, що на 4,69\% менше за нормативний показник зазначений в ЗУ «Про акціонерні товариства». Значну частку в структурі займає інший додатковий капітал підприємства - станом на 2014 та 2015 роки становить $25,25 \%$ та 28,61\% відповідно. Значне зменшення частки нерозподіленого прибутку в структурі ВК призводить до зростання таких елементів, як: статутний капітал, резервний капітал та інший додатковий капітал.

Структура ПАТ «Київенерго» відрізняється від ПАТ «Центренерго» (табл. 2). Так, частка статутного не перевищує $2 \%$ і найбільшого значення набуває в 2010 році - 1,74\% від загальної суми ВК. На 2014 рік статутний капітал складає 0,60\% і на першу половину 2015 збільшується на 0,08\%. Виходячи $з$ того, що абсолютне значення статутного фонду є незмінним динаміка його частки у ВК залежить від зміни інших компонентів ВК. В порівняні з ПАТ «Центренерго», підприємство 32012 року має в своїй структурі значну частку додатково вкладеного капіталу, який на 2012 рік склав 48,15\%, а на першу половину 2015 - 42,04\%. У структурі ВК присутній інший додатковий капітал, мінімум якого становив 31,96\% в 2012 році. Станом на 2015 рік він склав 44,33\%. У 2010 р. резервний капітал становив 4,16\%, а з 2011 - повністю відсутній на підприємстві, що суперечить існуючому законодавству України. Найбільш динамічною складовою структури ВК є інший додатковий вкладений капітал, середній темп зміни частки якого становить $(-20,7) \%$ починаючи з 2010 року. Середній темп зміни частки додатково вкладеного капіталу та нерозподіленого прибутку складає $+8,4 \%$ та $13,3 \%$ відповідно.

Статутний капітал ПАТ «Західенерго» в структурі власного капіталу становить 14,9\%. Згідно з результатами діяльності в 2011, 2012 та 2015pp. підприємство проводило переоцінку статутного капіталу, що призвело до зміни його вартості, а отже частки. Максимального значення частка статутного фонду досягає в 2012 році і становила 94,45\%. Додатковий вкладений капітал повністю відсутній; резервний фонд відсутній на підприємстві 32011 p. Інший додатковий капітал має спадний загальний тренд, проте за останні 3 роки - з 2013 по 2015 - ПАТ «Західенерго» значно наростило частку іншого капіталу - $322,51 \%$ до $85,04 \%$. Нерозподілений прибуток в даному випадку становить на момент 2015 року 0,06\% (табл. 2).

ПАТ «Донбасенерго» - єдине енергогенеруюче підприємство України серед досліджуваних, яке станом на першу половину 2015 р. одержало чистий прибуток розміром в 57957 тис. грн. У структурі ВК частка статутного фонду становить не менше 18\%, а саме 18,62\% в 2014 та 18,22\% в 2015 рр. 
Додатково вкладений капітал має тенденцію до зростання від 0\% в 2012 році до 33,28\% в 2015 р. ПАТ «Донбасенерго» майже досягло нормативного розміру резервного капіталу по відношенню до статутного фонду. В 2015 р. частка резервного фонду склала 14,91\%. 32011 року підприємство $є$ прибутковим і тому розмір частки нерозподіленого прибутку знаходиться в додатній зоні, хоча і має спадний тренд: з 78,63\% в 2013 році до 45,78\% в 2015 році (табл. 2).

Структура власного капіталу ПАТ «Дніпроенерго» $є$ найбільш повною 3 точки зору наявності елементів ВК (табл. 2). Тобто, в структурі ВК присутні частки статутного, резервного, додаткового фондів, іншого додаткового капіталу та нерозподіленого прибутку. Частки трьох елементів ВК мають спадний тренд: частка статутного фонду зменшується з 6,91\% до 1,98\% в 2014 p. i зростає на $0,13 \%$ на початку 2015 p. Середній темп зміни $(-0,96) \%$; середній темп зміни додатково вкладеного капіталу складає $(-6,44) \%$ річних - 3 2010 року по 2014 р. частка останнього зменшилась до $13,27 \%$ від загальної суми ВК, а в 2015 р. збільшився до рівня 14,18\%; інший додатковий капітал підприємства станом на першу половину 2015 р. становив 52,4\% - середній темп зміни складає $(-15,75) \%$. Резервний капітал в структурі ВК зростає в середньому на $0,01 \%$. В 2015 р. його частка в ВК становила $0,46 \%$ та $21,84 \%$ по відношенню до статутного капіталу. Нерозподілений прибуток мав зростаючу тенденцію до 2014 р., проте, в першій половині 2015 р. спостерігається зменшення його частини в загальному ВК.

Груповий аналіз показника забезпеченості власним капіталом показав, що загальний тренд по усім підприємствам є спадним (рис. 2). Щоправда, швидкість зміни, яка вимірюється тангенсом кута нахилу лінії тренду для ПАТ «Західенерго» $є$ більшою, ніж для інших підприємств. Причиною цього $\epsilon$ значна частка статутного фонду в структурі ВК станом на 2012 p.

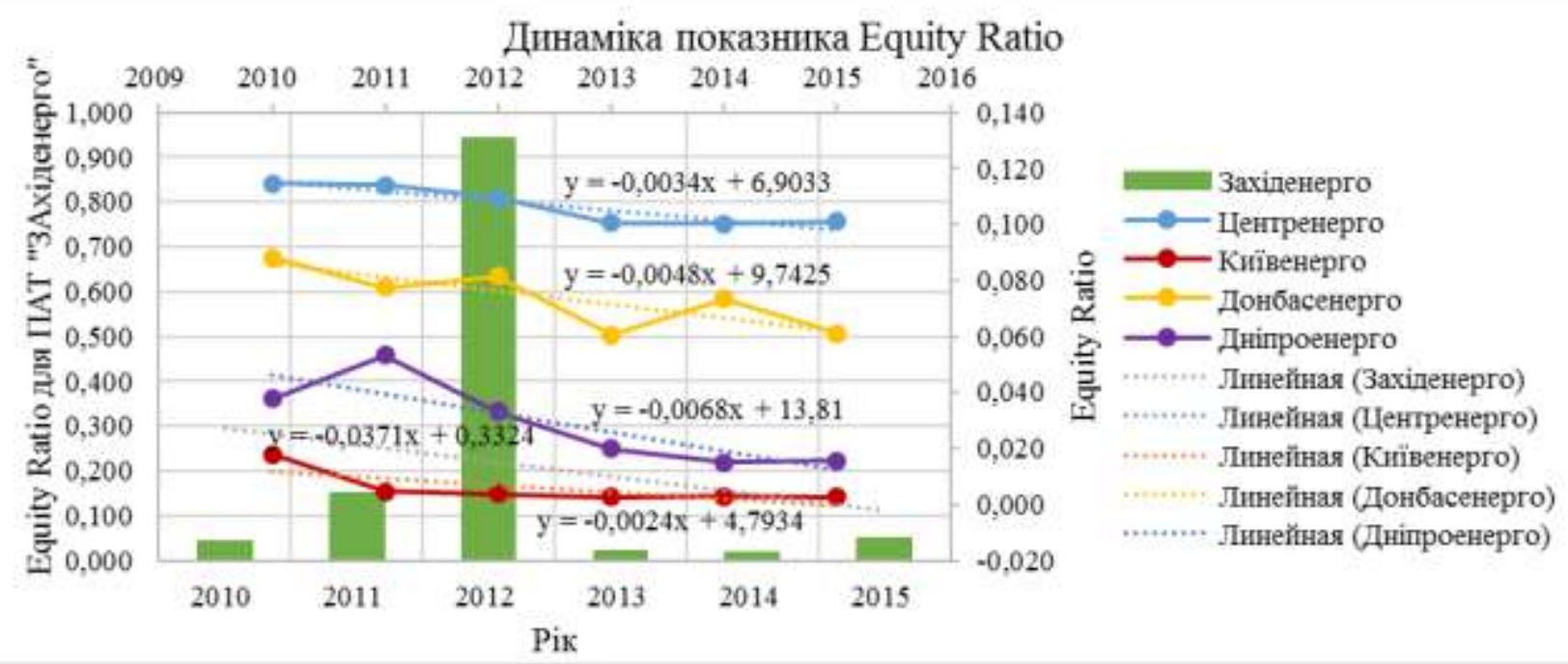

Рис. 2. Динаміка показника забезпеченості власним капіталом акціонерних товариств енергетики (побудовано на основі аналізу) 
Показник забезпеченості власним капіталом ПАТ «Центренерго» зменшується до рівня 0,100 в 2014 р. та зростає на 0,001 в першій половині 2015p. Така тенденція спостерігається за рахунок сталого розміру капіталу акціонерів та значного зростання активів підприємства. Це говорить про значне використання боргового капіталу для забезпечення фінансування діяльності. Забезпеченість власним капіталом ПАТ «Київенерго» становить 0,26\% станом на першу половину 2015 р. Загальний тренд даного показника $\epsilon$ спадний. Основною причиною цього виступають: сталий розмір статутного фонду, відсутність після 2010 року резервного капіталу, середня зміна нерозподіленого прибутку на 5,5\% та додатково залученого капіталу на 4\% протягом 6 років, а також значний приріст активів підприємства. Розрахунок показників ВК ПАТ «Західенерго» показав, що в 2014 р. активи підприємства були профінансовані за рахунок ВК лише на 1,6\%, а в 2015 р. на 4,7\%. Фінансування активів ПАТ «Донбасенерго» за рахунок ВК відбувається не менш ніж на 6\% в 2013 р. та на 6,1\% в 2015 р. Коефіцієнт забезпеченості власним капіталом ПАТ «Дніпроенерго» в 2014-2015 рр. становив 0,015, що $\epsilon$ мінімальним значенням 32010 р. Тобто, активи підприємства профінансовані за рахунок власного капіталу лише на 1,5\%.

Загальний тренд групи показника фінансового важеля є зростаючим для всіх обраних підприємств, проте, слід зазначити, що швидкість росту для ПАТ Київенерго, ПАТ Західенерго та ПАТ Дніпроенерго є найбільшою (рис. 3).

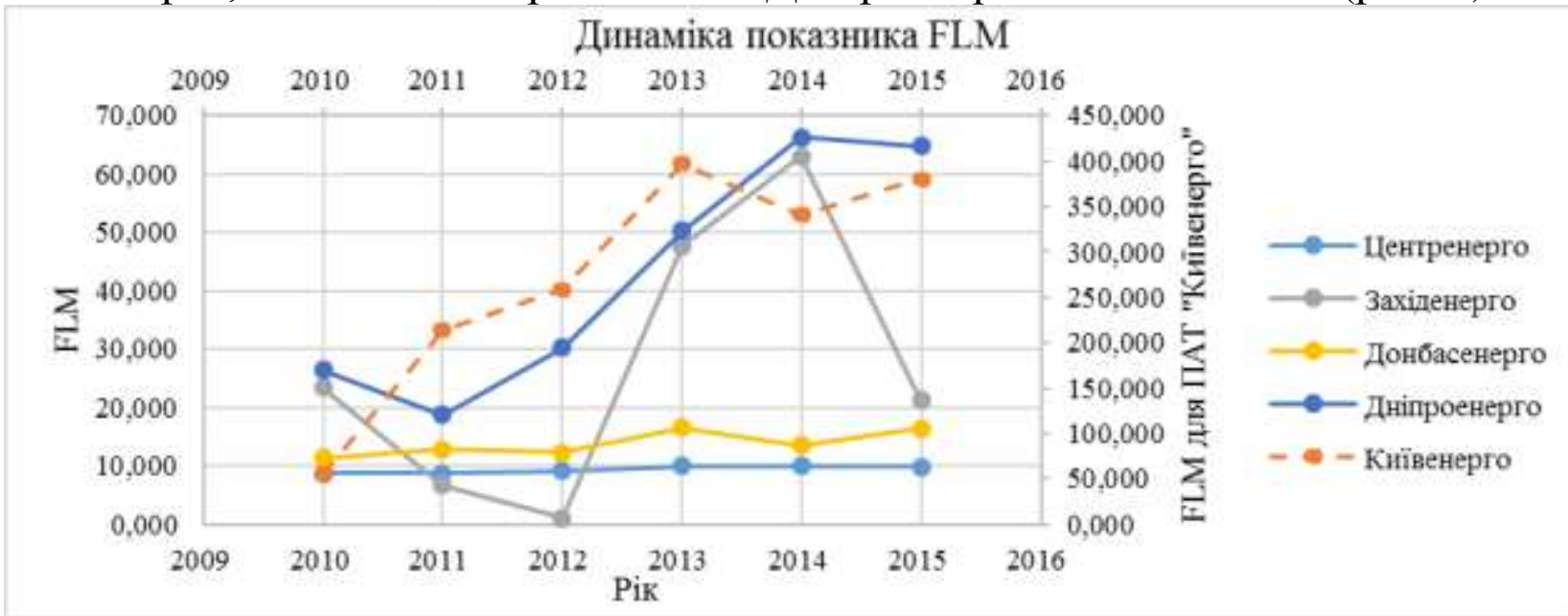

Рис. 3. Динаміка показника фінансового навантаження (побудовано на основі аналізу)

Підтвердженням використання ПАТ «Центренерго» боргового капіталу для фінансування власної діяльності, окрім показника забезпеченості власним капіталом, виступає також показник FLM, який має зростаючу тенденцію в 2010-2014 pр. В першій половині 2015 р. його значення зменшується на 0,075 за рахунок зменшення розміру загальних активів. Показник фінансового 
навантаження ПАТ «Київенерго» перевищує значення суми ВК більш ніж в 380 разів станом на 2015 рік. Це говорить про значний фінансовий тиск на підприємство. Важливу роль в цьому грає саме низька частка статутного і резервного фондів в структурі ВК. Згідно 3 показником FLM, ПАТ «Західенерго» значною мірою обтяжує себе фінансовими зобов'язаннями, оскільки значною мірою фінансується за рахунок боргового капіталу. Значення показника фінансового важеля склало 62,961 в 2014 р., а на першу половину 2015 р. - 21,205. Розмір показника фінансового навантаження для ПАТ «Донбасенерго» становить 16,381 , тобто - розмір активів підприємства перевищує ВК. Динаміка показника фінансового важеля для ПАТ «Дніпроенерго» є зростаючою. Так, в 2014 р. фінансове навантаження на підприємство становило 66,251, а в першій половині 64,729. Така волатильність показника фінансового важеля зумовлена значними змінами у структурі ВК. Якщо ж статутний фонд $є$ практично незмінним в абсолютному виразі, то вагомих зрушень зазнають інші елементи ВК, що, разом 3 неефективними фінансово-управлінськими рішеннями, i призводить до помітних диспропорцій.

Показники EPS i ROE по аналізованим підприємствам мають різну динаміку і загальний тренд $є$ спільним лише для 3 підприємств для показника прибутку на акцію (рис. 4), та 4 підприємств для показника рентабельності капіталу (рис. 5).

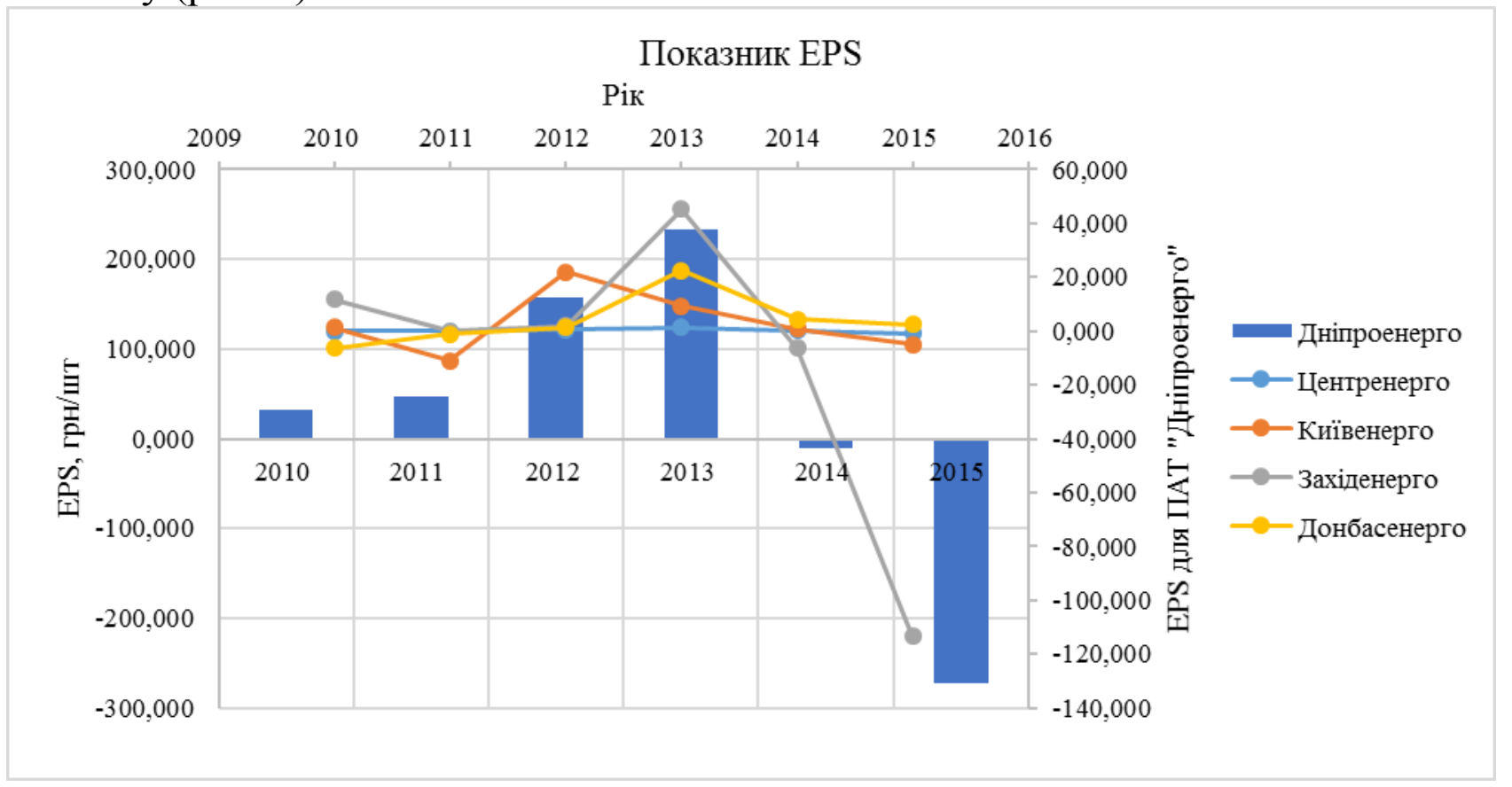

Рис. 4. Динаміка показника EPS енергетичних підприємств (побудовано на основі аналізу)

Показники ROE та EPS ПАТ «Центренерго» значною мірою залежать від прибутку ПАТ, оскільки кількість акцій та розмір статутного фонду даного 
підприємства $є$ константою, а інші складові власного капіталу можуть змінюватись не настільки швидко як прибуток. Отже, можна спостерігати, що ці показники для ПАТ «Центренерго» досягають свого максимуму в 2013 р. і становлять 101,41\% для ROE та 1,318 для EPS. Перша половина 2015 р. є «провальною» для ПАТ «Центренерго» через збитки розміром 268310 млн. грн.

Показники EPS i ROE ПАT «Київенерго» мають спадний хвилеподібний тренд через значні збитки, одержувані підприємством в 2011 та 2015 pp. Тому, станом на 2014 p. EPS становив 0,773 грн/шт, a ROE складав 309,28\%. Динаміка коефіцієнтів ROE і EPS ПАТ «Західенерго» знаходились в зоні додатних значень в 2013 році. В 2014 та 2015 роках, через значні збитки, рівень рентабельності на капітал та прибутковості на акцію знизились на ($296) \%$ та $(-113,5)$ грн/шт відповідно. Показники ПАТ «Донбасенерго» мають подібну динаміку. 32010 р. спостерігається зростання прибутку на одиницю акції з $(-6,257)$ грн/шт до 22,48 грн/шт в 2013 р. Через значне падіння рівня прибутку в 2014 р на 81\% - прибуток на одиницю акції склав 4,27 грн/шт. Тренд залишався спадним і в першій половині, що привело до зниження EPS до позначки 2,452 грн/шт. Паралельно до зміни прибутковості на акцію спостерігається зміна показника рентабельності капіталу. Таким чином, динаміка ROE є такою ж, як і динаміка EPS, - максимум 224,8\% був досягнутий в 2013 р., а в першій половині 2015 р. показник склав 24,51\%.

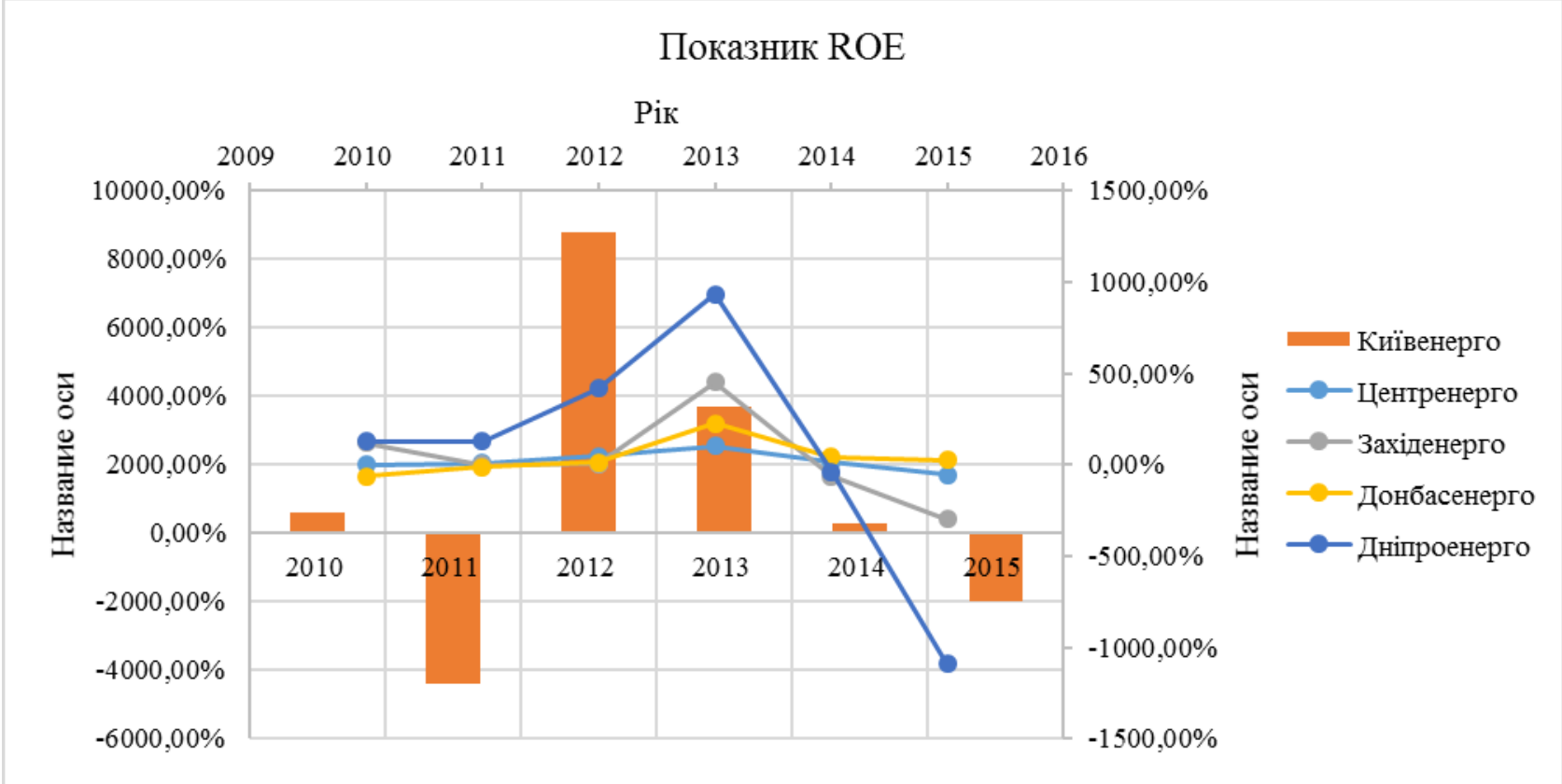

Рис. 5. Динаміка показника рентабельності капіталу акціонерних товариств електроенергетики (побудовано на основі аналізу)

Показник EPS максимального значення досягав в 2013 р. і становив 233,796 грн/шт. При цьому рентабельність капіталу складала 935,18\%. 32014 
р. ПАТ «Дніпроенерго» одержувало значні збитки, що вивело результати розрахунку даних показників у від'ємну зону - в першій половині 2015 року EPS склав $(-272,520)$ грн/шт, а ROE - $(-1090,08) \%$. EPS має тенденцію до зростання лише для ПАТ «Донбасенерго» та ПАТ «Центренерго» (рис. 4). Всі інші ПАТ показують спадний тренд.

Показник ROE знижується у всіх підприємств, окрім ПАT «Донбасенерго» (рис. 5). Така зміна була спричинена прибутком останнього, одержуваним в останні досліджувані періоди.

При вивчені показника P/E по групі підприємств досить складно визначити спільні характеристики та тренди (рис. 6). Подібність зміни показника спостерігається для ПАТ «Центренерго» та ПАТ «Дніпроенерго» а також для ПАТ Західенерго та ПАТ Донбасенерго у періоди 2010-2013 та 2013-2015 pp.

Якщо ж проаналізувати динаміку показників P/E та M/B, то можна сказати, що одночасного максимуму вони досягають в 2014 р. Причиною цього $є$ висока ринкова ціна одиниці акції, яку було визначено на основі даних ПФТС. Таким чином, в 2014 р. інвестори були готові платити за одиницю акції компанії в 38,604 рази більше за суму доходу на акцію, виходячи 3 розрахунку коефіцієнта Р/Е. Щодо коефіцієнта М/В, то він становив в 2014 р. 5,675 і визначав в скільки разів буде переоцінена одиниця акції компанії на фондовому ринку (рис. 7).

Коефіцієнт Р/Е для ПАТ «Київенерго» має хвилеподібну зміну протягом досліджуваного проміжку часу. В 2014 р. він досягав максимуму. В 2015 р. значення Р/Е було від'ємним, що було спричинено збитками підприємства.

P/E Ratio через збитковість ПАТ «Західенерго», набуває від'ємних значень в 2014-2015 pр. Станом на 2014 р. він склав (-22,21) та в 2015 році - (1,009). В 2015 р., згідно 3 коефіцієнтом М/В, інвестори оцінювали вартість акції майже в 3 рази більше (рис. 7). Хоча в 2014 р. показник склав 13,993. В 2012 р. інвестори готові були платити 15,761 грн для одержання одиниці прибутку на акцію ПАТ «Донбасенерго», а вже в 2013 р. спостерігається значне падіння даного коефіцієнта до рівня 1,222. В 2015 році він становив 7,828 . 


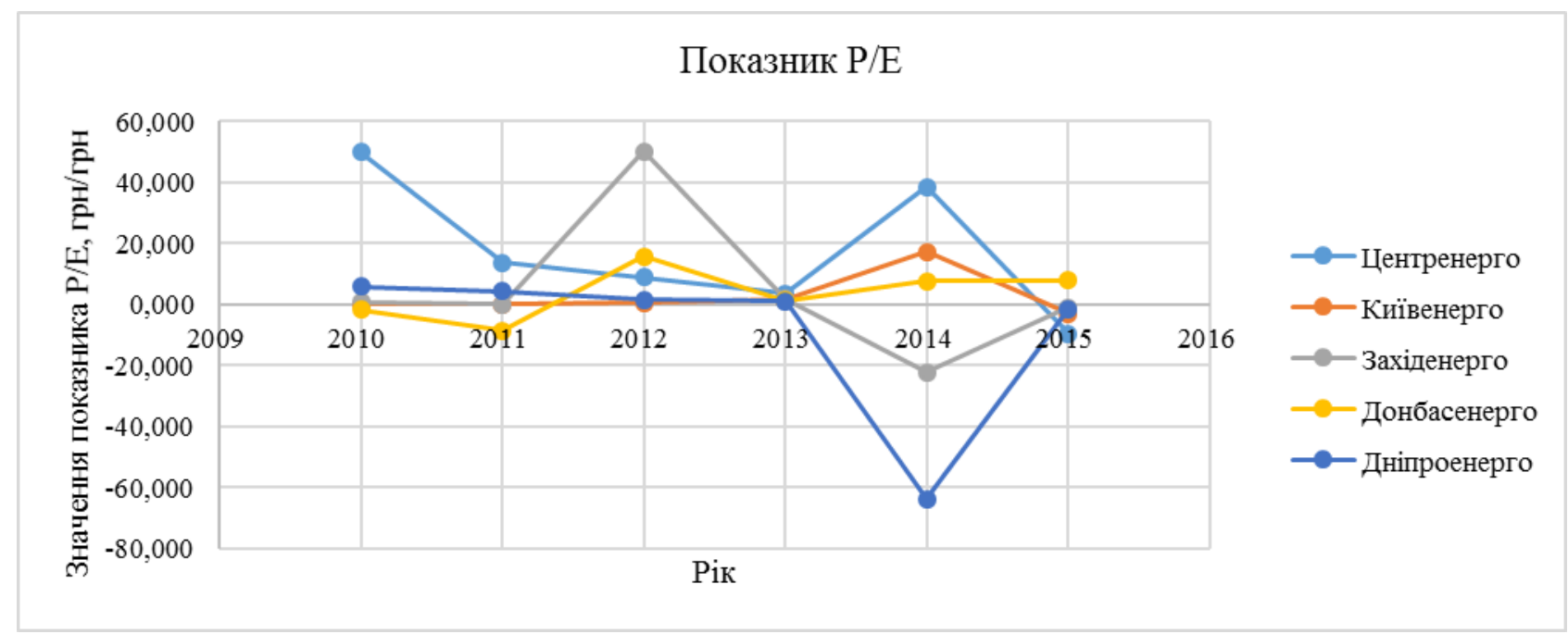

Рис. 6. Динаміка показника ціна/прибуток акціонерних товариств енергетики (побудовано на основі аналізу)

Динаміка зміни показника M/B $є$ зростаючою для всіх підприємств, щоправда в перші половині 2015 р. ПАТ «Київенерго» показало позитивний приріст, а той час як інші підприємства погіршили своє становище в даному напрямку (рис. 7). Спостерігається збільшення коефіцієнта М/В для ПАТ «Київенерго». У першій половині 2015 р. інвестори на фондовому ринку оцінювали вартість акцій компанії в 59,984 рази більше за їх номінальну.

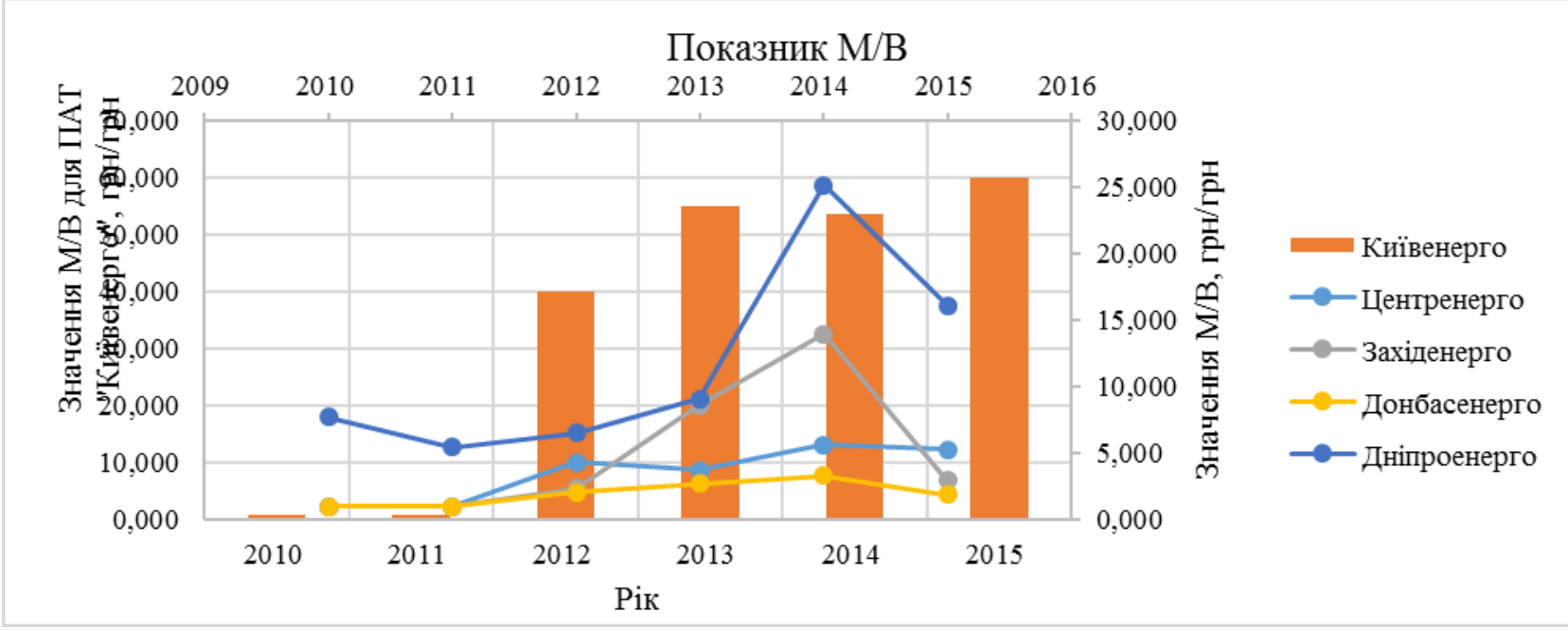

Рис. 7. Динаміка показника ринкова/номінальна вартість акції (побудовано на основі аналізу)

Динаміка М/В показника ПАТ «Донбасенерго» $є$ подібною до динаміки цього самого показника на ПАТ «Центренерго» та ПАТ «Західенерго» максимум його припадає на 2014 р. і становить 3,320. Тобто, ціна акції компанії в 2014 р. була переоцінена в 3,320 рази. В першій половині 2015 р. спад активності привів до зниження М/В до рівня 1,919. Номінальна вартість 
одиниці акції ПАТ «Дніпроенерго» становить 25 грн. Показник Р/Е станом на 2015 рік склав $(-1,48)$ грн/грн - причиною від'ємного значення $є$ отримані збитки за першу половину 2015 року. При цьому показник М/В складає 16,137 , проте це на $35,9 \%$ менше за попередній звітний період.

Проведена діагностика ефективності структури власного капіталу енергогенеруючих компаній та його структурних зрушень свідчить про наступне: усі обрані для дослідження енергогенеруючі акціонерні товариства, окрім ПАТ «Західенерго», характеризуються середнім ступенем динамічності структури власного капіталу. Проте, ПАТ «Західенерго» характеризується високим ступенем волатильності елементів структури власного капіталу, що говорить про неефективність фінансово-управлінських рішень та недосконалість фінансової політики. ПАТ «Центренерго», ПАТ «Київенерго», ПАТ «Донбасенерго» та ПАТ «Дніпроенерго»- мають середню ефективність структури ВК. Враховуючи загальні тренди, існує загроза падіння ефективності структури ВК в довгостроковій перспективі; для аналізованих підприємств мають такі загальні тенденції структури ВК: нестабільна зміна рівня чистого прибутку та загальної кількості активів; тренд зміни частки статутного фонду в загальній структурі ВК для всіх підприємств є спадним; частка нерозподіленого прибутку/непокритого збитку має нерівномірно зростаючий тренд; спільною для підприємств є спадна зміна частки іншого додаткового капіталу протягом 2010-2013 рр. та зростаючий тренд з 2013 по $2015 \mathrm{pp}$.

Висновки. У процесі дослідження удосконалено науково-методичний підхід до діагностики ефективності структури власного капіталу енергогенеруючих акціонерних товариств, який, на відміну від наявних, враховує етапність здійснення діагностики та дає можливість розглядати власний капітал у розрізі його структурних елементів у динаміці, а також дозволяє надавати практичні рекомендації щодо удосконалення управління структурою власного капіталу на основі зовнішньо- i внутрішньоорієнтованих показників (Equity Ratio, FLM, ROE, EPS, M/B Ratio, P/E Ratio). Дані показники доцільно використовувати через їх простоту, інформативність та логічність.

Теоретичне та практичне значення результатів дослідження полягає у не лише у виділені підходу до діагностування ефективності структури власного капіталу, а і наданні рекомендацій щодо удосконалення управління нею через: оптимізацію структури власного капіталу шляхом збільшення та додержання його загального розміру до 9-15\% від загальної кількості активів підприємства; зменшення рівня фінансового навантаження за рахунок погашення частини короткострокової заборгованості та підтримки іiі частки на рівні не більше частки довгострокових зобов'язань; оптимізацію випуску частини акцій підприємства у вільний рух на фондовому ринку для 
забезпечення доступу до зовнішніх джерел фінансування; врахування загально-ринкових тенденцій з метою адаптації підприємства до змін.

$B$ перспективах подальших наукових розробок за даним напрямом планується інтегрувати пропонований підхід у загальний комплекс діагностики структури капіталу енергогенеруючих акціонерних товариств, що дасть змогу чітко визначати ефективність різних джерел фінансування, їх структури та напрями управління ними.

\section{Лiтература:}

1. Мойсеєнко І.П. Інвестування : Навч. посіб. [Електронний ресурс] / І.П. Мойсеєнко. - К.: Знання, 2006. -

490с. Режим доступу: http://pidruchniki.com/15341220/investuvannya/optimizatsiya_strukturi_ kapitalu

2. Організація і методика економічного аналізу. Навч. посіб. [Електронний ресурс] / Т.Д. Косова, П.М. Сухарев, Л.О. Ващенко та ін. - К.: Центр учбової літератури, 2012. -

528 с. Режим доступу: http://pidruchniki.com/15410104/ekonomika/analiz_nayavnosti_skladu_ dinamiki_dzherel_formuvannya_kapitalu\#488

3. Фінансовий менеджмент : підручник [Електронний ресурс] / В.П. Мартиненко, Н.І. Климаш, К.В. Багацька, І.В. Дем'яненко, та ін. / за заг. ред. Т.А. Говорушко. - Львів "Магнолія 2006", 2014. -

344c. Режим доступу: http://pidruchniki.com/1056041264646/finansi/optimizatsiya_strukturi_k apitalu

4. Balvers R.J. Money and the C-CAPM [Printed edition] / Ronald J. Balvers, Dayoung Huang / University of Washington, Seattle: Journal of financial and quantitative analysis. - Vol. 44, No. 2. - Apr. 2009. - pp. 337-368.

5. Rădulescu A. An econometric model for estimating the equity risk premium [Printed edition] / Andrei Rădulescu and Daniel Traian Pele / Procedia Economics and Finance. Vol. 10. - 2014. - pp. 185 - 189.

6. Investment terms. Capital analysis ratios : Investopedia [Електронний ресурс] / Investopedia, LLC. - 2015. Режим доступу: http://www.investopedia.com/

7. Equity Ratio and Equity Multiplier Ratio : MyAccouuntingCourse [Електронний pecypc] / MyAccouuntingCourse.Com. - 2014. Режим доступу: http://www.myaccountingcourse.com/

8. Market Investigation. Energy sector : Bloomberg Business [Електронний pecypc] / Bloomberg L.P. - 2015. Режим доступу: http://www.bloomberg.com/markets/stocks/futures 